\title{
PENENTUAN TEBAL PELAT LANTAI GEDUNG YANG DITUMPU PADA KEEMPAT SISINYA SESUAI SNI 2847:2013
}

\author{
Oleh : I Gusti Ngurah Eka Partama *)
}

\begin{abstract}
ABSTRAK
Ketebalan minimum pelat beton bertulang non-prategang di dalam Persyaratan Beton Struktural untuk Bangunan Gedung (SNI 2847:2013) diatur dalam Pasal 9.5.3. Pada kondisi riil di lapangan ketebalan pelat lantai gedung ditetapkan secara empirik sebesar $12 \mathrm{~cm}$. Panel pelat lantai yang luasnya lebih dari $12 \mathrm{~m}^{2}$ atau bentang sisi pelat yang lebih dari 4 meter cendrung solusi yang diambil dengan menempatkan balok anak.

Analisa perhitungan tebal minimum pelat beton yang ditumpu pada keempat sisinya dengan bentang balok sepanjang $\mathrm{L}$ untuk gedung dilakukan dengan menggunakan model yang divariasikan menurut : dimensi panel pelat, dimensi balok yang menumpu sisi pelat dengan estimasi tinggi penampang balok (ht) sebesar 1/12.L - 1/10.L lebar balok (bw) diestimasi 1/2.ht 2/3.ht, mutu baja tulangan rencana dan variasi kondisi sisi pelat menerus dan tidak menerus.

Hasil analisa menunjukkan bahwa variasi dimensi balok menyebabkan ratio rata-rata kekakuan balok dengan kekakuan pelat $\left(\alpha_{m}\right)$ tetap lebih besar dari 2, sehingga tebal minimum pelat beton pada gedung menggunakan formula adalah $\mathrm{h}=\left\{\mathrm{L}_{\mathrm{n}} /(0,8+f y / 1400)\right\} /(36+9 \beta)$; tetapi tidak boleh kurang dari $90 \mathrm{~mm}$. Dengan demikian dari formula itu dapat dilihat bahwa variasi dimensi balok tidak memberikan pengaruh yang signifikan dalam menentukan tebal pelat. Variasi mutu baja tulangan menunjukkan tebal minimum pelat sebesar $90 \mathrm{~mm}$ untuk dimensi panel $4 \times 4 \mathrm{~m}^{2}$ dan baru menunjukkan ketebalan lebih besar dari $90 \mathrm{~mm}$ untuk panel berdimensi $5 \times 3 \mathrm{~m}^{2}$. Variasi menerus atau tidak menerusnya sisi pelat juga menunjukkan $\alpha_{\mathrm{m}}$ lebih besar dari 2, sehingga variasi ini juga tidak memberikan pengaruh yang signifikan terhadap ketebalan pelat. Variasi dimensi panel pelat memberikan pengaruh yang signifikan terhadap ketebalan pelat hal ini dapat dilihat dari formula $\mathrm{h}$ yang merupakan fungsi dari Ln (bentang bersih arah memanjang) dan $\beta$ (Ratio panjang sisi panjang dengan panjang sisi pendek).

Secara keseluruhan ketebalan pelat lantai gedung yang ditumpu pada keempat sisinya untuk berbagai dimensi panel pelat sebagai berikut : panel pelat $3 \times 3 \mathrm{~m}^{2}$ tebal pelat $=90 \mathrm{~mm}$, panel pelat $4 \times 3 \mathrm{~m}^{2}$ tebal pelat $=90 \mathrm{~mm}$, panel pelat $4 \times 4 \mathrm{~m}^{2}$ tebal pelat $=95 \mathrm{~mm}$, panel pelat $5 \times 3 \mathrm{~m}^{2}$ tebal pelat $=105 \mathrm{~mm}$, panel pelat $5 \times 4 \mathrm{~m}^{2}$ tebal pelat $=110 \mathrm{~mm}$, panel pelat $5 \times 5 \mathrm{~m}^{2}$ tebal pelat $=115 \mathrm{~mm}$, panel pelat $6 \times 3 \mathrm{~m}^{2}$ tebal pelat $=115 \mathrm{~mm}$, panel pelat $6 \times 4 \mathrm{~m}^{2}$ tebal pelat $=125 \mathrm{~mm}$ panel pelat $6 \times 5$ $\mathrm{m}^{2}$ tebal pelat $=135 \mathrm{~mm}$, panel pelat $6 \times 6 \mathrm{~m}^{2}$ tebal pelat $=140 \mathrm{~mm}$ dan panel pelat $7 \times 6 \mathrm{~m}^{2}$ tebal pelat $=155 \mathrm{~mm}$.
\end{abstract}

Kata Kuci : Tebal, Minimum, Pelat, Beton

\section{ABSTRACT}

The minimum thickness of the non-prestressed reinforced concrete plates in Indonesian Concrete Structural Code (SNI 2847:2013) is set forth in Section 9.5.3. In real conditions in the field the thickness of the building floor plate is set empirically by $12 \mathrm{~cm}$. Floor plates covering more than $12 \mathrm{~m}^{2}$ or span side plates more than 4 meters tends to be the solution taken by placing the second beam.

The minimum thickness analysis of the concrete plates supported on all four sides with a beam span along $L$ for the building was performed using the model varied according to the dimensions of the plate panel, the dimensions of the beam that supported the side of the plate with the estimated height of the cross section (ht) of 1/12.L - 1/10.L beam width (bw) is estimated 1/2.ht - 2/3.ht, reinforcement steel grades and variations of continuous and non-continuous plate-side conditions. 
The result of the analysis shows that the dimension of beam dimension causes the average rigidity ratio of beam with plate stiffness $\left(\alpha_{m}\right)$ to remain larger than 2 , so that minimum thickness of concrete plate in building using formula is $h=\frac{L_{n}\left(0,8+\frac{f y}{1400}\right)}{36+9 \beta}$; but may not less than 90 $\mathrm{mm}$. The formula can be seen that variation of dimension section beam not give significant influence which in determining is thick of slab. Variation of steel grade show thickly of slab is equal to $90 \mathrm{~mm}$ for the dimension of panel until $4 x 4 \mathrm{~m}^{2}$ and bigger than $90 \mathrm{~mm}$ when slab have dimension $5 \times 3 \mathrm{~m}^{2}$. Variation of continue or not continue side end of slab also show the $\alpha_{m}$ bigger than 2, so that this variation of not give siginificant influence which thick of slab. Dimension slab panel variation of give siginificant influence is thick of slab, this matter can be seen from $h$ formula representing function of Ln (span cleanness) and $\beta$ (Ratio of long side by short side length).

Overall the thickness of the building floor plates supported on all four sides for the various dimensions of the plate panel are as follows : plate panel $3 \times 3 \mathrm{~m}^{2}$ thickness $=90 \mathrm{~mm}$, plate panel $4 \times 3 \mathrm{~m}^{2}$ thickness $=90 \mathrm{~mm}$, plate panel $4 \times 4 \mathrm{~m}^{2}$ thickness $=95 \mathrm{~mm}$, plate panel $5 \times 3 \mathrm{~m}^{2}$ thickness $=$ $105 \mathrm{~mm}$, slab $5 \times 4 \mathrm{~m}^{2}$ thickness $=110 \mathrm{~mm}$, plate panel $5 \times 5 \mathrm{~m}^{2}$ thickness $=115 \mathrm{~mm}$, plate panel $6 \times 3$ $m^{2}$ thickness $=115 \mathrm{~mm}$, plate panel $6 \times 4 \mathrm{~m}^{2}$ thickness $=125$, plate panel $6 \times 5 \mathrm{~m}^{2}$ thickness $=135$ $\mathrm{mm}$, plate panel $6 \times 6 \mathrm{~m}^{2}$ thickness $=140 \mathrm{~mm}$ and plate panel $7 x 6 \mathrm{~m}^{2}$ thickness $=155 \mathrm{~mm}$.

Key Word : Thick, Minimum, Slab, Concrete

\section{PENDAHULUAN}

\subsection{Latar Belakang}

Sistem pelat lantai gedung beton bertulang umumnya bidang pelat lantainya ditumpu pada setiap sisinya oleh balok induk atau balok anak. Secara empirik ketebalan pelat lantai gedung ditetapkan sebesar $12 \mathrm{~cm}$, kemudian untuk panel pelat lantai yang luasnya lebih dari $12 \mathrm{~m}^{2}$ atau bentang sisi pelat yang lebih dari 4 meter cendrung solusi yang diambil dengan menempatkan balok anak. Solusi ini diambil untuk menghindari perhitungan yang rumit, namun berdampak pada penggunaan beton menjadi boros.

Upaya untuk mendapatkan ketebalan pelat yang efektif dan efisien harus dilakukan kalkulasi yang cermat sesuai dengan ketentuan yang tercantum dalam standar-standar yang berlaku sehingga biaya yang dibutuhkan dipilih yang paling rendah tanpa mengabaikan aspek keamanan dan keselamatan.

Kajian ini akan berupaya untuk mendapatkan tebal pelat lantai dalam berbagai dimensi panel pelat yang ditumpu pada keempat sisinya sesuai SNI 2847:2013.

\subsection{Permasalahan}

Permasalahan yang diangkat di dalam penelitian ini adalah berapa tebal pelat lantai gedung yang ideal tanpa memasang balok anak sebagai pengaku. 


\subsection{Tujuan Penelitian}

Tujuan penelitian ini adalah menentukan tebal pelat lantai gedung yang ideal tanpa memasang balok anak sebagai pengaku.

\subsection{Metode Penelitian}

Penelitian ini dilakukan dengan menggunakan model yang dirancang sendiri oleh peneliti untuk selanjutnya dilakukan analisa dan perhitungan sesuai ketentuan SNI 2847:2013.

\section{LANDASAN TEORI}

\subsection{Pelat Dua Arah (Two way slab)}

Pelat Dua Arah yaitu : pelat yang mendukung atau memikul beban (Momen Lentur) dalam dua arah.

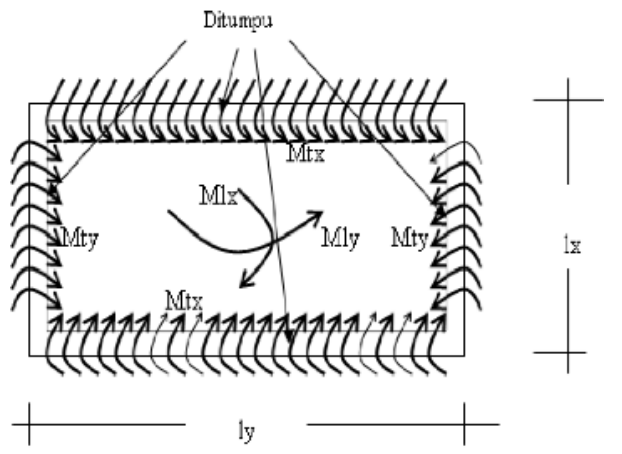

Mtx = Momen tumpuan searah sisi pendek

$\mathrm{Mlx}=$ Momen lapangan searah sisi pendek

Mty = Momen tumpuan searah sisi panjang

Mly = Momen lapangan searah sisi panjang

Gambar 1. Distribusi Momen Lentur pada pelat 2 arah yang ditumpu pada 4 sisinya

Harga Mtx, Mlx, Mty dan Mly ditentukan berdasarkan nilai Ly/Lx dan Tabel 13.3.2 Pada Peraturan Beton Indonesia 1971 (PBI '71.

\subsection{Perencanaan Tebal minimum Pelat Dua Arah}

Tebal pelat minimum dengan balok yang menumpunya pada semua sisi diatur dalam Pasal 9.5.3 SNI 2847:2013 yang terdiri :

a. Untuk $\alpha_{m}$ yang sama atau lebih kecil dari $0,2\left(\alpha_{m} \leq 0,2\right)$ harus menggunakan pasal 9.5.3.2

b. Untuk $\alpha_{m}$ yang lebih besar dari 0,2 tetapi tidak lebih dari $2\left(0,2<\alpha_{m} \leq 2\right)$ tebal minimum pelat ditentukan dengan persamaan : 
$\mathrm{h}=\frac{L_{n}\left(0,8+\frac{f y}{1400}\right)}{36+5 \beta\left\{\alpha_{m}-0,2\right\}} ;$ tetapi tidak boleh kurang dari $125 \mathrm{~mm}$

c. Untuk $\alpha_{\mathrm{m}}$ yang lebih besar dari $2\left(\alpha_{m} \geq 2\right)$ tebal pelat ditentukan dengan persamaan :

$\mathrm{h}=\frac{L_{n}\left(0,8+\frac{f y}{1400}\right)}{36+9 \beta}$; tetapi tidak boleh kurang dari $90 \mathrm{~mm}$

dimana :

$\mathrm{h}=$ tebal minimum pelat $(\mathrm{mm})$

$\mathrm{L}_{\mathrm{n}}=\mathrm{L}_{\mathrm{n} 1}=$ Panjang bersih pelat dalam arah memanjang $(\mathrm{mm})(\mathrm{Nawy}, 1990)$

fy $=$ Tegangan leleh baja/mutu baja (dalam MPa)

$\beta=\frac{L_{n 1}}{L_{n 2}} ; \quad \mathrm{L}_{\mathrm{n} 1}=$ bentang bersih dalam arah panjang $(\mathrm{mm})$

$\mathrm{L}_{\mathrm{n} 2}=$ bentang bersih dalam arah pendek $(\mathrm{mm})$

$\alpha=$ Perbandingan kekakuan balok dengan kekakuan pelat $=\frac{E_{c b} I_{b}}{E_{c s} I_{s}}$

$\mathrm{E}_{\mathrm{cb}}=$ Modulus Elastisitas Beton

$\mathrm{E}_{\mathrm{cs}}=$ Modulus Elastisitas Pelat

$\mathrm{I}_{\mathrm{b}} \quad=$ Momen Inersia balok (dalam penampang $\mathrm{T}$ atau $\Gamma$ )

$\mathrm{I}_{\mathrm{s}}=$ Momen Inersia pelat yang bersesuaian dengan balok

Penampang balok dengan bentuk penampang " $\mathrm{T}$ ” atau " $\Gamma$ " untuk perhitungan momen inersia terhadap sumbu-X (Ix) dapat dihitung dengan formula : $I_{b}=k \cdot \frac{1}{12} \cdot b w \cdot h t^{3}$ dengan nilai $\mathrm{k}$ dihitung sebagai berikut :

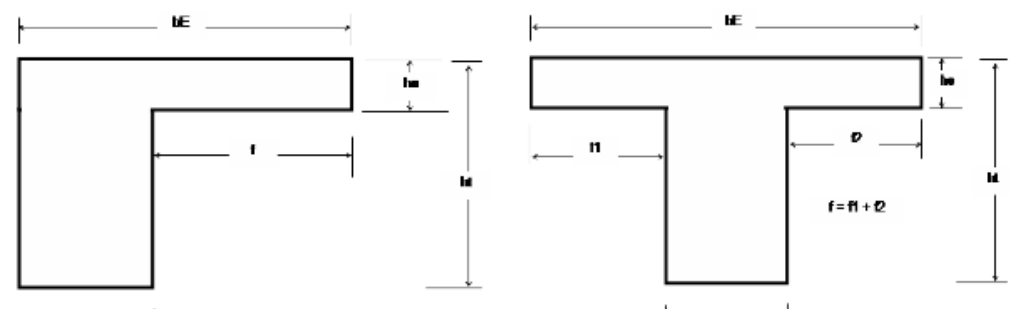

Gambar 2. Notasi dimensi bentuk penampang balok “ $\mathrm{T}$ ” atau " $\Gamma$ " untuk menghitung Momen Inersia terhadap sumbu mendatar (Ix)

$k=1+\left\{\left(\frac{b E}{b w}-1\right)\left(\frac{h o}{h t}\right)^{3}\right\}+\left\{\frac{3\left(\frac{b E}{b w}-1\right)\left(1-\frac{h o}{h t}\right)^{2} \cdot \frac{h o}{h t}}{1+\left(\frac{b E}{b w}-1\right) \cdot \frac{h o}{h t}}\right\}($ Nawy, 1990) 


$$
\begin{aligned}
& k=\left\{\frac{1+\left(\frac{b E}{b w}-1\right)\left(\frac{h o}{h t}\right)\left[4-6\left(\frac{h o}{h t}\right)+4\left(\frac{h o}{h t}\right)^{2}+\left(\frac{h o}{h t}-1\right)\left(\frac{h o}{h t}\right)^{3}\right]}{1+\left(\frac{b E}{b o}-1\right) \cdot \frac{h o}{h t}}\right\} \text { atau (Wang, et. al, 1987) } \\
& \alpha_{m}=\text { ratio rata-rata kekakuan balok dengan pelat }=\frac{\alpha_{1}+\alpha_{2}+\alpha_{3}+\alpha_{4}}{4}
\end{aligned}
$$

Pada Pasal 9.5.3.4 SNI 2847:2013 disebutkan pelat dengan tebal kurang dari tebal minimum yang ditetapkan dalam Pasal 9.5.3.3 boleh digunakan bila dapat ditunjukkan dengan perhitungan bahwa lendutan yang terjadi tidak melampaui batas lendutan yang ditetapkan pada Tabel 95 (b).

\section{ANALISA DAN PEMBAHASAN}

\subsection{Model Penelitian}

Model dibuat dengan menyusun dimensi panel pelat lantai yang sering dilaksanakan dalam pembangunan gedung bertingkat. Panel-Panel pelat lantai yang ditinjau yaitu panel pelat dengan keempat sisi menerus, panel pelat dengan tiga sisi menerus, panel pelat dengan dua sisi menerus, panel pelat dengan satu sisi menerus dan panel pelat dengan sisi tidak ada yang menerus yang masing-masing kasusnya dapa dilihat pada Gambar 3.

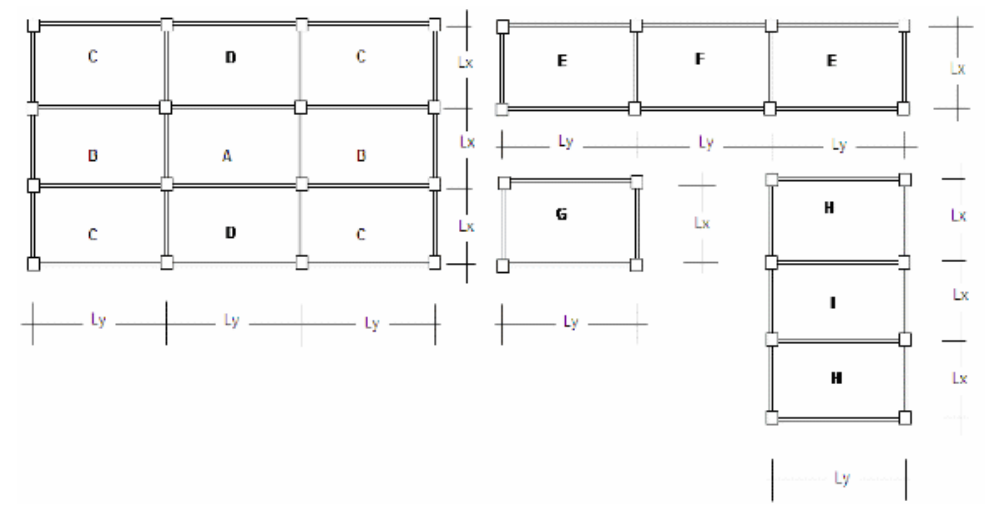

Gambar 3. Model panel pelat lantai

Huruf yang tercantum pada masing-masing panel pelat pada Gambar 6 menunjukkan masing-masing kasus. Huruf A menunjukkan panel pelat untuk kasus keempat sisi pelat menerus, Huruf B menunjukkan panel pelat salah satu sisi pendek pelat tidak menerus dan sisi lainnya menerus, Huruf C menunjukkan satu sisi panjang dan sisi pendek pelat menerus dan yang lainnya tidak menerus, Huruf D menunjukkan satu sisi panjang tidak menerus dan sisi lainnya menerus, Huruf E menunjukkan salah satu sisi 
pendek pelat menerus dan sisi lainnya tidak menerus, Huruf $F$ menunjukkan dua sisi pendek pelat menerus dan dua sisi panjang tidak menerus, Huruf E menunjukkan semua sisi pendek tidak menerus, Huruf $\mathrm{H}$ menunjukkan salah satu sisi panjang pelat menerus dan sisi lainnya tidak menerus dan Huruf I menunjukkan salah dua sisi pendek pelat tidak menerus dan dua sisi panjang menerus.

Dimensi balok diestimasi berdasarkan panjang bentang yang bersesuaian. Untuk lebar balok (bw) diestimasi $1 / 2$ sampai $2 / 3$ dari tinggi penampang balok (1/2.ht $-2 / 3$.ht), sedangkan tinggi penampang balok (ht) diestimasi sebesar 1/12 sampai 1/10 kali panjang bentang balok $(1 / 12 . \mathrm{L}-1 / 10 . \mathrm{L})$.

Dimensi panel pelat (Lx dan Ly) yang ditinjau bervariasi yaitu :
a. $3 \mathrm{~m} \times 3 \mathrm{~m}$
b. $4 \mathrm{~m} \times 3 \mathrm{~m}, 4 \mathrm{mx} 4 \mathrm{~m}$
c. $5 \mathrm{~m} \times 3 \mathrm{~m}, 5 \mathrm{~m} \times 4 \mathrm{~m}, 5 \mathrm{~m} \times 5 \mathrm{~m}$
d. $6 \mathrm{mx} 3 \mathrm{~m}, 6 \mathrm{mx} 4 \mathrm{~m}, 6 \mathrm{mx} 5 \mathrm{~m}, 6 \mathrm{mx} 6 \mathrm{~m}$

\subsection{Perhitungan Tebal minimum Pelat Lantai}

Perhitungan tebal pelat ditinjau untuk masing-masing kasus yaitu : panel pelat untuk kasus keempat sisi pelat menerus, panel pelat untuk kasus tiga sisi pelat menerus, panel pelat untuk kasus dua sisi pelat menerus, panel pelat untuk kasus satu sisi pelat menerus dan panel pelat untuk kasus semua sisi pelat tidak menerus. Sebagai contoh perhitungan diambil panel pelat $\mathrm{C}$ seperti Gambar 4.

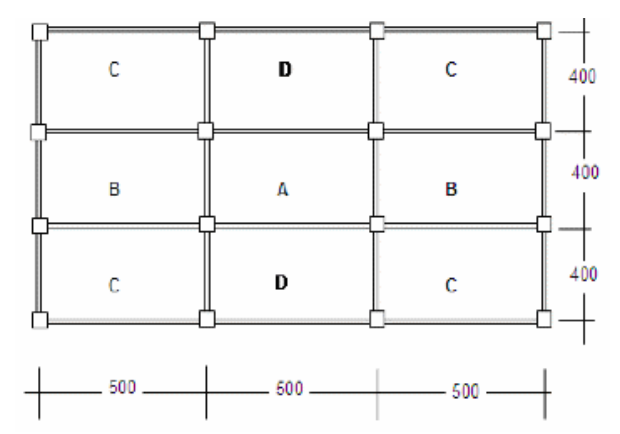

Gambar 4. Model panel pelat lantai untuk contoh perhitungan

Satuan dalam cm; Dimensi balok sisi pendek $25 \times 40 \mathrm{~cm}$ dan dimensi balok sisi panjang 30x50 $\mathrm{cm}$; Mutu baja tulangan fy $=240 \mathrm{MPa}$

Perhitungan tebal pelat lantai tersebut dilakukan dengan prosedur sebagai berikut :

1. Estimasi awal tebal pelat (ho)

Tebal pelat sebagai estimasi awal perlu ditentukan karena saat peninjauan Besaran Inersia balok, balok penumpu pelat ditinjau sebagai balok dengan bentuk penampang 
" $\mathrm{T}$ " untuk balok yang memikul pelat yang menerus dan " $\Gamma$ " untuk balok yang memikul pelat yang tidak menerus. Estimasi awal tebal pelat (ho) pada contoh perhitungan ini ditentukan sebesar $12 \mathrm{~cm}$

2. Tentukan as-as pelat baik arah memanjang maupun melintang/memendek untuk panel pelat terpilih dan panel pelat di sekeliling panel pelat terpilih. Perhatikan Gambar 8 .

3. Balok-balok tumpuan pelat terpilih diberi nomor 1, 2, 3 dan 4 (penomoran bebas) Perhatikan Gambar 5.

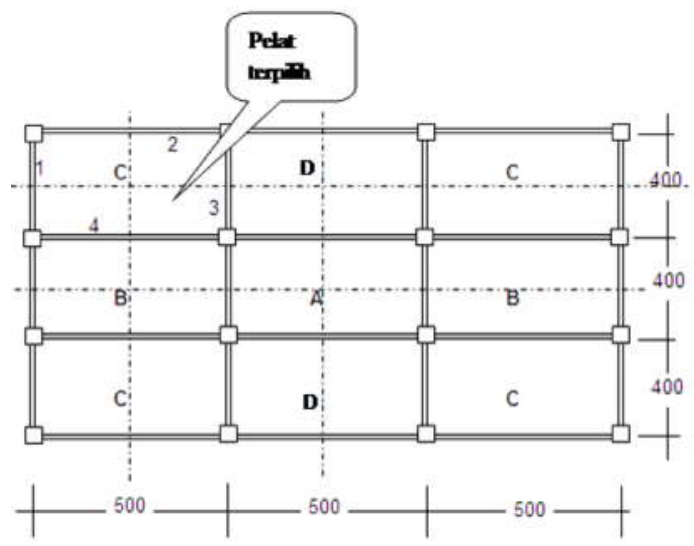

Gambar 5. Penomoran balok dan penentuan as pelat pada dan di sekeliling pelat terpilih

4. Menentukan rasio rata-rata kekakuan balok dengan pelat $\left(\alpha_{m}\right)$

Sebelum menghitung rasio kekakuan balok dan pelat, terlebih dahulu harus ditentukan dimensi efektif balok, Inersia Balok $\left(\mathrm{I}_{\mathrm{b}}\right)$ dan Inersia Pelat $\left(\mathrm{I}_{\mathrm{s}}\right)$.

a. Dimensi Efektif dan Inersia Balok 1

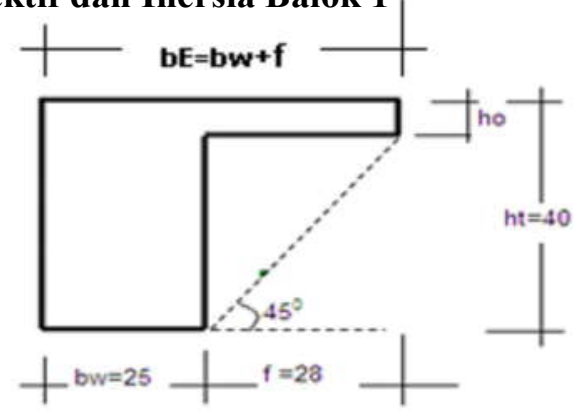

Gambar 6. Dimensi penampang balok nomor 1 untuk contoh perhitungan

$\mathrm{f}=\mathrm{h}_{\mathrm{t}}-\mathrm{h}_{\mathrm{o}}$ harus $\leq 4 . \mathrm{h}_{\mathrm{o}}($ Pasal 13.2.4 SNI 2847:2013)

$$
=40-12=28 \mathrm{~cm} \leq 4.12=4
$$

$\mathrm{b}_{\mathrm{E}}=\mathrm{b}_{\mathrm{W}}+\mathrm{f}=25+28=53 \mathrm{~cm}$

$$
\frac{h o}{h t}=\frac{12}{40}=0,30 ; \frac{b E}{b w}=\frac{53}{25}=2,12
$$




$$
\begin{aligned}
& I_{b 1}=k \cdot \frac{1}{12} \cdot b w \cdot h t^{3} \\
& k=1+\left\{\left(\frac{b E}{b w}-1\right)\left(\frac{h o}{h t}\right)^{3}\right\}+\left\{\frac{3\left(\frac{b E}{b w}-1\right)\left(1-\frac{h o}{h t}\right)^{2} \cdot \frac{h o}{h t}}{1+\left(\frac{b E}{b w}-1\right) \cdot \frac{h o}{h t}}\right\} \\
&=1+\left\{(2,12-1)(0,30)^{3}\right\}+\left\{\frac{3(2,12-1)(1-0,30)^{2} \cdot 0,30}{1+(2,12-1) \cdot 0,30}\right\}=1,400 \\
& I_{b 1}=1,400 \cdot \frac{1}{12} \cdot 25 \cdot 40^{3}=186 \cdot 659 \mathrm{~cm}^{4}
\end{aligned}
$$

\section{b. Dimensi efektif dan inersia balok 2}

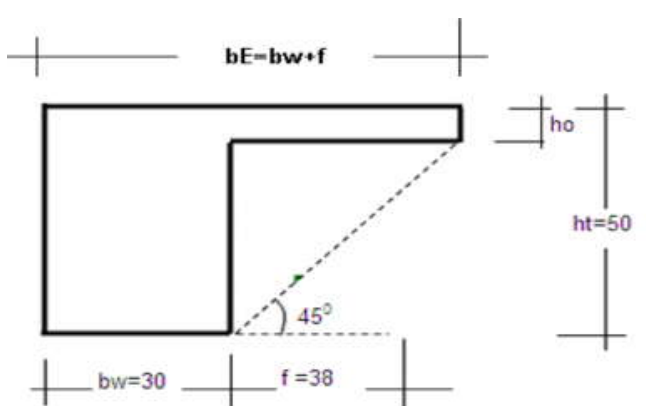

Gambar 7. Dimensi penampang balok nomor 2 untuk contoh perhitungan

$$
\begin{aligned}
& \mathrm{f}=\mathrm{h}_{\mathrm{t}}-\mathrm{h}_{\mathrm{o}} \text { harus } \leq 4 \cdot \mathrm{h}_{\mathrm{o}}(\text { Pasal 13.2.4 SNI 2847:2013) } \\
&=50-12=38 \mathrm{~cm} \leq 4 \cdot 12=48(\mathrm{O} \cdot \mathrm{K}) \\
& \mathrm{bE}=\mathrm{b}_{\mathrm{W}}+\mathrm{f}=30+38=68 \mathrm{~cm} \\
& \frac{h o}{h t}=\frac{12}{50}=0,24 ; \frac{b E}{b w}=\frac{68}{30}=2,27 \\
& I_{b 2}=k \cdot \frac{1}{12} \cdot b w \cdot h t^{3} \\
& k=1+\left\{\left(\frac{b E}{b w}-1\right)\left(\frac{h o}{h t}\right)^{3}\right\}+\left\{\frac{3\left(\frac{b E}{b w}-1\right)\left(1-\frac{h o}{h t}\right)^{2} \cdot \frac{h o}{h t}}{1+\left(\frac{b E}{b w}-1\right) \cdot \frac{h o}{h t}}\right\} \\
&=1+\left\{(2,27-1)(0,24)^{3}\right\}+\left\{\frac{3(2,27-1)(1-0,24)^{2} \cdot 0,24}{1+(2,27-1) \cdot 0,24}\right\}=1,422
\end{aligned}
$$




$$
I_{b 2}=1,422 \cdot \frac{1}{12} \cdot 30 \cdot 50^{3}=444 \cdot 480 \mathrm{~cm}^{4}
$$

\section{c. Dimensi Efektif dan Inersia Balok 3}

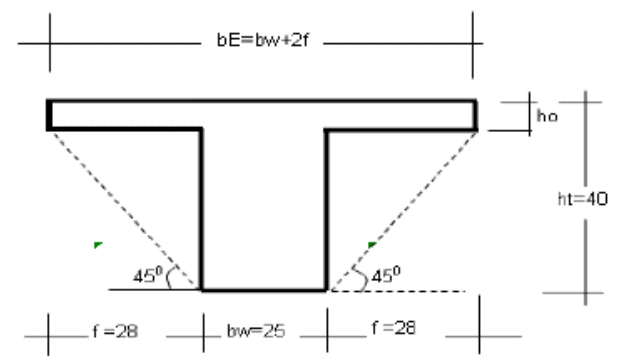

Gambar 8. Dimensi penampang balok nomor 3 untuk contoh perhitungan

$$
\begin{aligned}
\mathrm{f} & =\mathrm{h}_{\mathrm{t}}-\mathrm{h}_{\mathrm{o}} \quad=40-12=28 \mathrm{~cm} \\
\mathrm{~b}_{\mathrm{E}} & =\mathrm{b}_{\mathrm{W}}+2 \mathrm{f} \text { harus } \leq \mathrm{b}_{\mathrm{W}}+8 \cdot \mathrm{h}_{\mathrm{o}}(\text { Pasal } 15 \cdot 2 \cdot 4 \text { SNI } 03-2847-2002) \\
& =(25+2 \cdot 28=81 \mathrm{~cm}) \leq(25+8 \cdot 12=121 \mathrm{~cm}) \text { O.K } \\
\frac{h o}{h t} & =\frac{12}{40}=0,30 ; \frac{b E}{b w}=\frac{81}{25}=3,24 \\
I_{b 3} & =k \cdot \frac{1}{12} \cdot b w \cdot h t^{3} \\
k=1 & +\left\{\left(\frac{b E}{b w}-1\right)\left(\frac{h o}{h t}\right)^{3}\right\}+\left\{\frac{3\left(\frac{b E}{b w}-1\right)\left(1-\frac{h o}{h t}\right)^{2} \cdot \frac{h o}{h t}}{1+\left(\frac{b E}{b w}-1\right) \cdot \frac{h o}{h t}}\right\} \\
=1 & +\left\{(3,24-1)(0,30)^{3}\right\}+\left\{\frac{3(3,24-1)(1-0,30)^{2} \cdot 0,30}{1+(3,24-1) \cdot 0,30}\right\}=1,651 \\
I_{b 3} & =1,651 \cdot \frac{1}{12} \cdot 25 \cdot 40^{3}=220 \cdot 172 \mathrm{~cm}{ }^{4}
\end{aligned}
$$

\section{d. Dimensi efektif dan inersia balok $4\left(I_{b 4}\right)$}

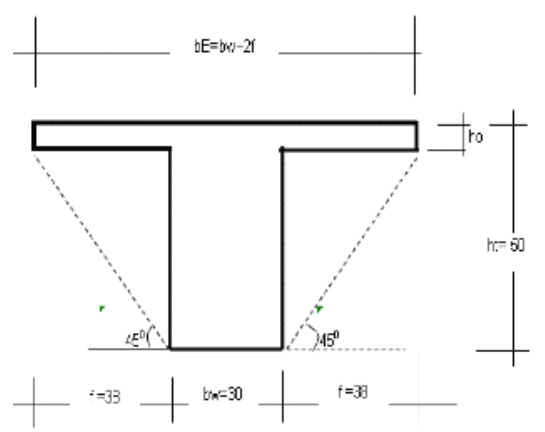

Gambar 9. Dimensi penampang balok nomor 2 untuk contoh perhitungan 


$$
\begin{aligned}
& \mathrm{f}=\mathrm{h}_{\mathrm{t}}-\mathrm{h}_{\mathrm{o}} \quad=40-12=28 \mathrm{~cm} \\
& \mathrm{~b}_{\mathrm{E}}=\mathrm{b}_{\mathrm{W}}+2 \mathrm{f} \text { harus } \leq \mathrm{b}_{\mathrm{W}}+8 \cdot \mathrm{h}_{\mathrm{o}}(\text { Pasal 13.2.4 SNI 2847:2013 } \\
&=(30+2 \cdot 38=106 \mathrm{~cm}) \leq(30+8 \cdot 12=126 \mathrm{~cm}) \mathrm{O} \cdot \mathrm{K} \\
& \frac{h o}{h t}=\frac{12}{50}=0,24 ; \frac{b E}{b w}=\frac{106}{30}=3,53 \\
& I_{b 4}=k \cdot \frac{1}{12} \cdot b w \cdot h t^{3} \\
& k=1+\left\{\left(\frac{b E}{b w}-1\right)\left(\frac{h o}{h t}\right)^{3}\right\}+\left\{\frac{3\left(\frac{b E}{b w}-1\right)\left(1-\frac{h o}{h t}\right)^{2} \cdot \frac{h o}{h t}}{1+\left(\frac{b E}{b w}-1\right) \cdot \frac{h o}{h t}}\right\} \\
&=1+\left\{(3,53-1)(0,24)^{3}\right\}+\left\{\frac{3(3,53-1)(1-0,24)^{2} \cdot 0,24}{1+(3,53-1) \cdot 0,24}\right\}=1,69 \\
& I_{b 4}=1,69 \cdot \frac{1}{12} \cdot 30 \cdot 50^{3}=528 \cdot 008 \mathrm{~cm}^{4}
\end{aligned}
$$

e. Inersia pelat yang bersesuaian dengan balok $1\left(\mathrm{I}_{\mathrm{s} 1}\right)$

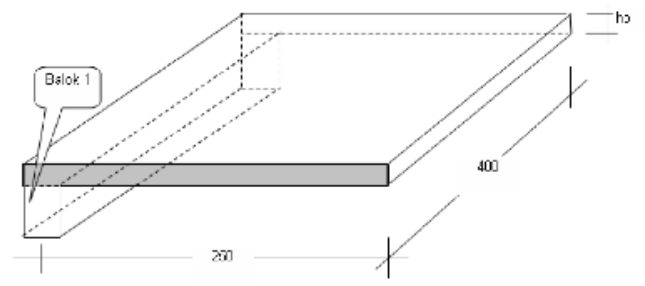

Gambar 10. Dimensi penampang pelat bersesuaian dengan balok nomor 1 untuk contoh perhitungan

Momen Inersia dihitung sesuai penampang yang diarsir (sesuai dengan arah potongan melintang balok 1)

$$
I_{s 1}=\frac{1}{12} \cdot b_{1} \cdot h_{1}^{3} ; I_{s 1}=\frac{1}{12} \cdot 250 \cdot 12^{3}=36.000 \mathrm{~cm}^{4}
$$

f. Inersia pelat yang bersesuaian dengan balok $2\left(\mathrm{I}_{\mathrm{s} 2}\right)$

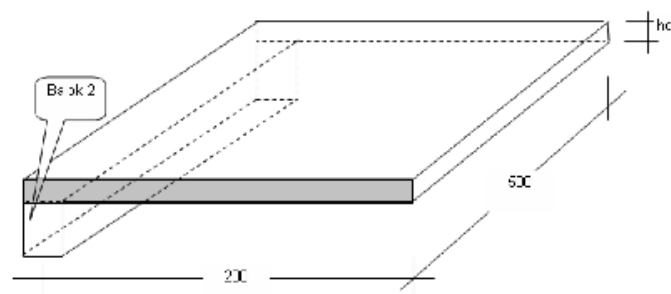

Gambar 11. Dimensi penampang pelat bersesuaian dengan balok nomor 2 untuk contoh perhitungan 
Momen Inersia di hitung sesuai penampang yang diarsir (sesuai dengan arah potongan melintang balok 2)

$$
I_{s 2}=\frac{1}{12} \cdot b_{2} \cdot h_{2}{ }^{3} ; I s_{2}=\frac{1}{12} \cdot 200 \cdot 12^{3}=28.800 \mathrm{~cm}^{4}
$$

g. Inersia pelat yang bersesuaian dengan balok $3\left(\mathrm{Is}_{3}\right)$

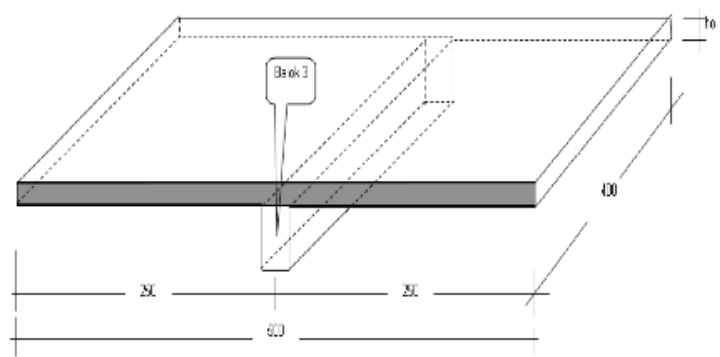

Gambar 12. Dimensi penampang pelat bersesuaian dengan balok nomor 3 untuk contoh perhitungan

$$
I_{s 3}=\frac{1}{12} \cdot b_{3} \cdot h_{3}^{3} ; I s_{3}=\frac{1}{12} \cdot 500 \cdot 12^{3}=72.000 \mathrm{~cm}^{4}
$$

h. Inersia Ppelat yang bersesuaian dengan balok $4\left(\mathrm{I}_{54}\right)$

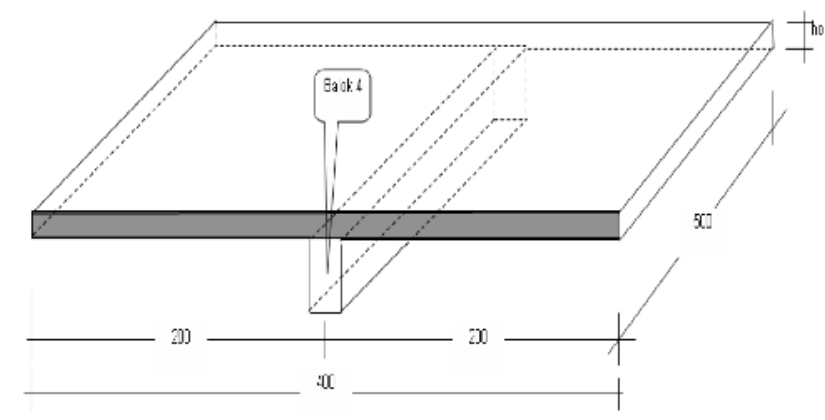

Gambar 13. Dimensi penampang pelat bersesuaian dengan balok nomor 4 untuk contoh perhitungan

$$
I_{s 4}=\frac{1}{12} \cdot b_{3} \cdot h_{3}^{3} ; I s_{4}=\frac{1}{12} \cdot 400 \cdot 12^{3}=57.600 \mathrm{~cm}^{4}
$$

i. Perhitungan Ratio Kekakuan Balok dengan pelat rata-rata $\left(\alpha_{\mathrm{m}}\right)$

$$
\begin{aligned}
& \alpha_{1}=\frac{E c b \cdot I_{b 1}}{E c s \cdot I_{s 1}}=\frac{186 \cdot 659}{36.000}=5,185 ; \alpha_{2}=\frac{E c b \cdot I_{b 2}}{E c b \cdot I_{s 2}}=\frac{444 \cdot 480}{28.800}=15,433 \\
& \alpha_{3}=\frac{E c b \cdot I_{b 3}}{E c b \cdot I_{s 3}}=\frac{220.172}{72.000}=3,058 ; \alpha_{4}=\frac{E c b \cdot I_{b 4}}{E c b \cdot I_{s 4}}=\frac{528.008}{57 \cdot 600}=9,167 \\
& \alpha_{m}=\frac{\sum \alpha i}{4}=\frac{\alpha_{1}+\alpha_{2}+\alpha_{3}+\alpha_{4}}{4}=\frac{5,185+15,433+3,058+9,167}{4}=8,211
\end{aligned}
$$


5. Menentukan tebal minimum pelat (h)

Hasil perhitungan rasio kekakuan balok dan pelat rata-rata $\left(\alpha_{\mathrm{m}}\right)$ didapat sebesar 8,211 yang lebih besar dari $2\left(\alpha_{\mathrm{m}} \geq 2\right)$ dengan demikian tebal pelat ditentukan dengan persamaan :

$\mathrm{h}=\frac{L_{n}\left(0,8+\frac{f y}{1400}\right)}{36+9 \beta} ;$ tetapi tidak boleh kurang dari $90 \mathrm{~mm}$

Panjang bentang bersih masing-masing sisi pelat adalah :

$\mathrm{L}_{\mathrm{n} 1}=500-25=475 \mathrm{~cm} ; \mathrm{L}_{\mathrm{n} 2}=400-30=370 \mathrm{~cm}$

Rasio antara bentang besih sisi panjang terhadap sisi pendek adalah :

$\beta=\frac{L_{n 1}}{L_{n 2}}=\frac{475}{370}=1,284$

sehingga $: h=\frac{475\left(0,8+\frac{240}{1400}\right)}{36+9.1,284}=\frac{475(0,97)}{47,556}=9,70 \mathrm{~cm}$

Tebal pelat yang dicoba pada awal perhitungan yaitu ho $=12 \mathrm{~cm}$ memenuhi syarat tetapi masih terlalu boros dibandingkan dengan tebal pelat yang disyaratkan. Untuk mengupayakan tebal pelat yang ideal dan ekonomis perhitungan diulangi dengan menentukan nilai ho $=10 \mathrm{~cm}$ (sedikit diatas tebal pelat hasil perhitungan dengan rumus (h) dan angka bulat).

6. Perhitungan ulang tebal pelat dengan mencoba ho $=10 \mathrm{~cm}$

Perhitungan ulang dilakukan dengan melakukan perhitungan mulai dari langkah ke-4 di atas dengan hasil sebagai berikut :

a. Inersia balok

$$
\begin{aligned}
& I b_{1}=1,409 \cdot \frac{1}{12} \cdot 25 \cdot 40^{3}=186 \cdot 867 \mathrm{~cm}^{4} ; I_{b 2}=1,412 \cdot \frac{1}{12} \cdot 30 \cdot 50^{3}=441 \cdot 250 \mathrm{~cm}^{4} \\
& I_{b 3}=1,669 \cdot \frac{1}{12} \cdot 25 \cdot 40^{3}=222 \cdot 533 \mathrm{~cm}^{4} \\
& I_{b 4}=1,689 \cdot \frac{1}{12} \cdot 30 \cdot 50^{3}=527 \cdot 813 \mathrm{~cm}^{4}
\end{aligned}
$$

b. Inersia pelat

$$
\begin{aligned}
& I S_{1}=\frac{1}{12} \cdot b_{1} \cdot h_{1}^{3}=\frac{1}{12} \cdot 250 \cdot 10^{3}=20.833 \mathrm{~cm}^{4} \\
& I S_{2}=\frac{1}{12} \cdot b_{2} \cdot h_{2}^{3}=\frac{1}{12} \cdot 200 \cdot 10^{3}=16.667 \mathrm{~cm}^{4}
\end{aligned}
$$




$$
\begin{aligned}
& I s_{3}=\frac{1}{12} \cdot b_{3} \cdot h_{3}^{3}=\frac{1}{12} \cdot 500 \cdot 10^{3}=41 \cdot 667 \mathrm{~cm}^{4} \\
& I S_{4}=\frac{1}{12} \cdot b_{3} \cdot h_{3}^{3}=\frac{1}{12} \cdot 400 \cdot 10^{3}=33.333 \mathrm{~cm}^{4}
\end{aligned}
$$

c. Perhitungan ratio kekakuan balok dengan pelat rata-rata $\left(\alpha_{\mathrm{m}}\right)$

$$
\begin{aligned}
& \alpha_{1}=\frac{E c b \cdot I b_{1}}{E c s \cdot I s_{1}}=\frac{186 \cdot 867}{20.833}=8,97 ; \alpha_{2}=\frac{E c b \cdot I b_{2}}{E c s \cdot I s_{2}}=\frac{441 \cdot 250}{16 \cdot 667}=26,47 \\
& \alpha_{3}=\frac{E c b \cdot I b_{3}}{E c s \cdot I s_{3}}=\frac{222.533}{41.667}=5,34 ; \alpha_{4}=\frac{E c b \cdot I b_{4}}{E c s \cdot I s_{4}}=\frac{527 \cdot 813}{33 \cdot 333}=15,83 \\
& \alpha_{m}=\frac{\sum \alpha i}{4}=\frac{\alpha_{1}+\alpha_{2}+\alpha_{3}+\alpha_{4}}{4}=\frac{8,97+26,47+5,34+15,83}{4}=14,15
\end{aligned}
$$

d. Menentukan tebal minimum pelat (h)

Hasil perhitungan rasio kekakuan balok dan pelat rata-rata $\left(\alpha_{\mathrm{m}}\right)$ didapat sebesar 14,15 yang juga lebih besar dari $2\left(\alpha_{\mathrm{m}} \geq 2\right)$, sehingga tebal pelat dihitung dengan rumus yang sama menghasilkan nilai sama yaitu $9,70 \mathrm{~cm}$. Tebal pelat yang dicoba pada awal perhitungan yaitu ho $=10 \mathrm{~cm}$ memenuhi syarat dan cukup ekonomis, sehingga tebal pelat terpakai adalah $\mathrm{h}=10 \mathrm{~cm}$.

Contoh perhitungan tebal minimum pelat dua arah oleh Setiawan (2016) dengan dimensi panel $7 \mathrm{~m}$ x $6 \mathrm{~m}$ mendapat tebal pelat minimum 15,132 $\mathrm{cm}$ dan ditetapkan untuk

\begin{tabular}{|c|c|c|c|c|c|c|c|c|c|}
\hline \multirow{3}{*}{ No. } & \multicolumn{2}{|c|}{ Panel Pelat } & \multirow{3}{*}{$\begin{array}{c}\text { Estimasi } \\
\text { Awal } \\
\text { Tebal } \\
\text { Pelat } \\
\text { ho }[\mathrm{cm}]\end{array}$} & \multicolumn{4}{|c|}{ Dimensi Balok } & \multirow{3}{*}{$\begin{array}{l}\text { Mutu Baja } \\
\text { Tulangan } \\
\text { fy [MPa] }\end{array}$} & \multirow{3}{*}{$\begin{array}{l}\text { Tebal } \\
\text { Pelat } \\
\mathrm{h}[\mathrm{cm}]\end{array}$} \\
\hline & \multirow{2}{*}{$\begin{array}{c}\text { Sisi } \\
\text { Panjang } \\
\text { (Ly) } \\
{[\mathrm{m}]}\end{array}$} & \multirow{2}{*}{$\begin{array}{c}\text { Sisi } \\
\text { Pendek } \\
\text { (Lx) } \\
{[\mathrm{m}]}\end{array}$} & & \multicolumn{2}{|c|}{ Pada Sisi Panjang [cm] } & \multicolumn{2}{|c|}{ Pada Sisi Pendek [cm] } & & \\
\hline & & & & bw & ht & bw & ht & & \\
\hline \multirow{5}{*}{1} & 3 & 3 & 12 & 15 & 30 & 15 & 30 & 240 & 9,00 \\
\hline & 3 & 3 & 12 & 15 & 30 & 15 & 30 & 320 & 9,00 \\
\hline & 3 & 3 & 12 & 15 & 30 & 15 & 30 & 350 & 9,00 \\
\hline & 3 & 3 & 12 & 15 & 30 & 15 & 30 & 390 & 9,00 \\
\hline & 3 & 3 & 12 & 15 & 30 & 15 & 30 & 400 & 9,00 \\
\hline \multirow{4}{*}{2} & 3 & 3 & 12 & 20 & 30 & 20 & 30 & 240 & 9,00 \\
\hline & 3 & 3 & 12 & 20 & 30 & 20 & 30 & 320 & 9,00 \\
\hline & 3 & 3 & 12 & 20 & 30 & 20 & 30 & 350 & 9,00 \\
\hline & 3 & 3 & 12 & 20 & 30 & 20 & 30 & 390 & 9,00 \\
\hline
\end{tabular}
dimensi panel ini menggunakan mutu baja tulangan BJTD 40 ((fy=400 MPa) ketebalan pelat sebesar 15,50 $\mathrm{cm}$. Hasil perhitungan ketebalan pelat selengkapnya ditabelkan pada Tabel 1.

Tabel 1. Hasil perhitungan tebal pelat untuk seluruh kasus 


\begin{tabular}{|c|c|c|c|c|c|c|c|c|c|}
\hline & 3 & 3 & 12 & 20 & 30 & 20 & 30 & 400 & 9,00 \\
\hline \multirow{5}{*}{3} & 3 & 3 & 12 & 20 & 30 & 15 & 30 & 240 & 9,00 \\
\hline & 3 & 3 & 12 & 20 & 30 & 15 & 30 & 320 & 9,00 \\
\hline & 3 & 3 & 12 & 20 & 30 & 15 & 30 & 350 & 9,00 \\
\hline & 3 & 3 & 12 & 20 & 30 & 15 & 30 & 390 & 9,00 \\
\hline & 3 & 3 & 12 & 20 & 30 & 15 & 30 & 400 & 9,00 \\
\hline \multirow{5}{*}{4} & 3 & 3 & 12 & 15 & 30 & 20 & 30 & 240 & 9,00 \\
\hline & 3 & 3 & 12 & 15 & 30 & 20 & 30 & 320 & 9,00 \\
\hline & 3 & 3 & 12 & 15 & 30 & 20 & 30 & 350 & 9,00 \\
\hline & 3 & 3 & 12 & 15 & 30 & 20 & 30 & 390 & 9,00 \\
\hline & 3 & 3 & 12 & 15 & 30 & 20 & 30 & 400 & 9,00 \\
\hline \multirow{5}{*}{5} & 4 & 3 & 12 & 20 & 40 & 15 & 30 & 240 & 9,00 \\
\hline & 4 & 3 & 12 & 20 & 40 & 15 & 30 & 320 & 9,00 \\
\hline & 4 & 3 & 12 & 20 & 40 & 15 & 30 & 350 & 9,00 \\
\hline & 4 & 3 & 12 & 20 & 40 & 15 & 30 & 390 & 9,00 \\
\hline & 4 & 3 & 12 & 20 & 40 & 15 & 30 & 400 & 9,00 \\
\hline \multirow{5}{*}{6} & 4 & 3 & 12 & 20 & 40 & 20 & 30 & 240 & 9,00 \\
\hline & 4 & 3 & 12 & 20 & 40 & 20 & 30 & 320 & 9,00 \\
\hline & 4 & 3 & 12 & 20 & 40 & 20 & 30 & 350 & 9,00 \\
\hline & 4 & 3 & 12 & 20 & 40 & 20 & 30 & 390 & 9,00 \\
\hline & 4 & 3 & 12 & 20 & 40 & 20 & 30 & 400 & 9,00 \\
\hline \multirow{5}{*}{7} & 4 & 3 & 12 & 25 & 40 & 15 & 30 & 240 & 9,00 \\
\hline & 4 & 3 & 12 & 25 & 40 & 15 & 30 & 320 & 9,00 \\
\hline & 4 & 3 & 12 & 25 & 40 & 15 & 30 & 350 & 9,00 \\
\hline & 4 & 3 & 12 & 25 & 40 & 15 & 30 & 390 & 9,00 \\
\hline & 4 & 3 & 12 & 25 & 40 & 15 & 30 & 400 & 9,00 \\
\hline \multirow{5}{*}{8} & 4 & 3 & 12 & 25 & 40 & 20 & 30 & 240 & 9,00 \\
\hline & 4 & 3 & 12 & 25 & 40 & 20 & 30 & 320 & 9,00 \\
\hline & 4 & 3 & 12 & 25 & 40 & 20 & 30 & 350 & 9,00 \\
\hline & 4 & 3 & 12 & 25 & 40 & 20 & 30 & 390 & 9,00 \\
\hline & 4 & 3 & 12 & 25 & 40 & 20 & 30 & 400 & 9,00 \\
\hline \multirow{5}{*}{9} & 4 & 4 & 12 & 20 & 40 & 20 & 40 & 240 & 9,00 \\
\hline & 4 & 4 & 12 & 20 & 40 & 20 & 40 & 320 & 9,00 \\
\hline & 4 & 4 & 12 & 20 & 40 & 20 & 40 & 350 & 9,00 \\
\hline & 4 & 4 & 12 & 20 & 40 & 20 & 40 & 390 & 9,50 \\
\hline & 4 & 4 & 12 & 20 & 40 & 20 & 40 & 400 & 9,50 \\
\hline \multirow{5}{*}{10} & 4 & 4 & 12 & 25 & 40 & 20 & 40 & 240 & 9,00 \\
\hline & 4 & 4 & 12 & 25 & 40 & 20 & 40 & 320 & 9,00 \\
\hline & 4 & 4 & 12 & 25 & 40 & 20 & 40 & 350 & 9,00 \\
\hline & 4 & 4 & 12 & 25 & 40 & 20 & 40 & 390 & 9,50 \\
\hline & 4 & 4 & 12 & 25 & 40 & 20 & 40 & 400 & 9,50 \\
\hline \multirow{5}{*}{11} & 4 & 4 & 12 & 20 & 40 & 25 & 40 & 240 & 9,00 \\
\hline & 4 & 4 & 12 & 20 & 40 & 25 & 40 & 320 & 9,00 \\
\hline & 4 & 4 & 12 & 20 & 40 & 25 & 40 & 350 & 9,00 \\
\hline & 4 & 4 & 12 & 20 & 40 & 25 & 40 & 390 & 9,50 \\
\hline & 4 & 4 & 12 & 20 & 40 & 25 & 40 & 400 & 9,50 \\
\hline \multirow{2}{*}{12} & 4 & 4 & 12 & 25 & 40 & 25 & 40 & 240 & 9,00 \\
\hline & 4 & 4 & 12 & 25 & 40 & 25 & 40 & 320 & 9,00 \\
\hline
\end{tabular}




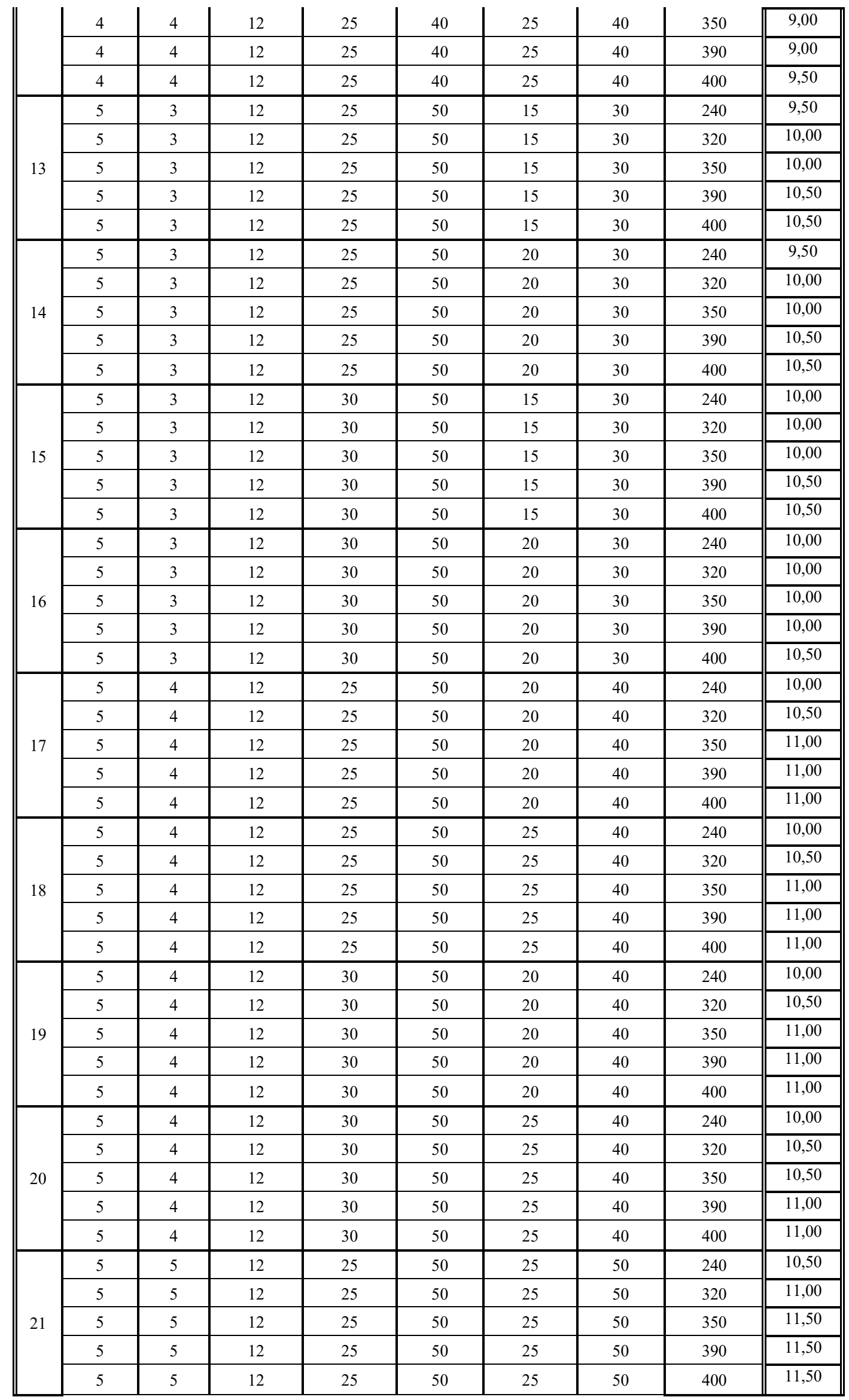




\begin{tabular}{|c|c|c|c|c|c|c|c|c|c|}
\hline \multirow{5}{*}{22} & 5 & 5 & 12 & 25 & 50 & 30 & 50 & 240 & 10,50 \\
\hline & 5 & 5 & 12 & 25 & 50 & 30 & 50 & 320 & 11,00 \\
\hline & 5 & 5 & 12 & 25 & 50 & 30 & 50 & 350 & 11,00 \\
\hline & 5 & 5 & 12 & 25 & 50 & 30 & 50 & 390 & 11,50 \\
\hline & 5 & 5 & 12 & 25 & 50 & 30 & 50 & 400 & 11,50 \\
\hline \multirow{5}{*}{23} & 5 & 5 & 12 & 30 & 50 & 25 & 50 & 240 & 10,50 \\
\hline & 5 & 5 & 12 & 30 & 50 & 25 & 50 & 320 & 11,00 \\
\hline & 5 & 5 & 12 & 30 & 50 & 25 & 50 & 350 & 11,50 \\
\hline & 5 & 5 & 12 & 30 & 50 & 25 & 50 & 390 & 11,50 \\
\hline & 5 & 5 & 12 & 30 & 50 & 25 & 50 & 400 & 11,50 \\
\hline \multirow{5}{*}{24} & 5 & 5 & 12 & 30 & 50 & 30 & 50 & 240 & 10,50 \\
\hline & 5 & 5 & 12 & 30 & 50 & 30 & 50 & 320 & 11,00 \\
\hline & 5 & 5 & 12 & 30 & 50 & 30 & 50 & 350 & 11,00 \\
\hline & 5 & 5 & 12 & 30 & 50 & 30 & 50 & 390 & 11,50 \\
\hline & 5 & 5 & 12 & 30 & 50 & 30 & 50 & 400 & 11,50 \\
\hline \multirow{5}{*}{25} & 6 & 3 & 12 & 30 & 60 & 15 & 30 & 240 & 10,50 \\
\hline & 6 & 3 & 12 & 30 & 60 & 15 & 30 & 320 & 11,00 \\
\hline & 6 & 3 & 12 & 30 & 60 & 15 & 30 & 350 & 11,50 \\
\hline & 6 & 3 & 12 & 30 & 60 & 15 & 30 & 390 & 11,50 \\
\hline & 6 & 3 & 12 & 30 & 60 & 15 & 30 & 400 & 11,50 \\
\hline \multirow{5}{*}{26} & 6 & 3 & 12 & 30 & 60 & 20 & 30 & 240 & 10,50 \\
\hline & 6 & 3 & 12 & 30 & 60 & 20 & 30 & 320 & 11,00 \\
\hline & 6 & 3 & 12 & 30 & 60 & 20 & 30 & 350 & 11,50 \\
\hline & 6 & 3 & 12 & 30 & 60 & 20 & 30 & 390 & 11,50 \\
\hline & 6 & 3 & 12 & 30 & 60 & 20 & 30 & 400 & 11,50 \\
\hline \multirow{5}{*}{27} & 6 & 3 & 12 & 40 & 60 & 15 & 30 & 240 & 10,50 \\
\hline & 6 & 3 & 12 & 40 & 60 & 15 & 30 & 320 & 11,00 \\
\hline & 6 & 3 & 12 & 40 & 60 & 15 & 30 & 350 & 11,00 \\
\hline & 6 & 3 & 12 & 40 & 60 & 15 & 30 & 390 & 11,50 \\
\hline & 6 & 3 & 12 & 40 & 60 & 15 & 30 & 400 & 11,50 \\
\hline \multirow{5}{*}{28} & 6 & 3 & 12 & 40 & 60 & 20 & 30 & 240 & 10,50 \\
\hline & 6 & 3 & 12 & 40 & 60 & 20 & 30 & 320 & 11,00 \\
\hline & 6 & 3 & 12 & 40 & 60 & 20 & 30 & 350 & 11,00 \\
\hline & 6 & 3 & 12 & 40 & 60 & 20 & 30 & 390 & 11,50 \\
\hline & 6 & 3 & 12 & 40 & 60 & 20 & 30 & 400 & 11,50 \\
\hline \multirow{5}{*}{29} & 6 & 4 & 12 & 30 & 60 & 20 & 40 & 240 & 11,50 \\
\hline & 6 & 4 & 12 & 30 & 60 & 20 & 40 & 320 & 12,00 \\
\hline & 6 & 4 & 12 & 30 & 60 & 20 & 40 & 350 & 12,50 \\
\hline & 6 & 4 & 12 & 30 & 60 & 20 & 40 & 390 & 12,50 \\
\hline & 6 & 4 & 12 & 30 & 60 & 20 & 40 & 400 & 13,00 \\
\hline \multirow{5}{*}{30} & 6 & 4 & 12 & 30 & 60 & 25 & 40 & 240 & 11,50 \\
\hline & 6 & 4 & 12 & 30 & 60 & 25 & 40 & 320 & 12,00 \\
\hline & 6 & 4 & 12 & 30 & 60 & 25 & 40 & 350 & 12,50 \\
\hline & 6 & 4 & 12 & 30 & 60 & 25 & 40 & 390 & 12,50 \\
\hline & 6 & 4 & 12 & 30 & 60 & 25 & 40 & 400 & 12,50 \\
\hline \multirow{3}{*}{31} & 6 & 4 & 12 & 40 & 60 & 20 & 40 & 240 & 11,50 \\
\hline & 6 & 4 & 12 & 40 & 60 & 20 & 40 & 320 & 12,00 \\
\hline & 6 & 4 & 12 & 40 & 60 & 20 & 40 & 350 & 12,50 \\
\hline
\end{tabular}




\begin{tabular}{|c|c|c|c|c|c|c|c|c|c|}
\hline & 6 & 4 & 12 & 40 & 60 & 20 & 40 & 390 & 12,50 \\
\hline & 6 & 4 & 12 & 40 & 60 & 20 & 40 & 400 & 12,50 \\
\hline \multirow{5}{*}{32} & 6 & 4 & 12 & 40 & 60 & 25 & 40 & 240 & 11,50 \\
\hline & 6 & 4 & 12 & 40 & 60 & 25 & 40 & 320 & 12,00 \\
\hline & 6 & 4 & 12 & 40 & 60 & 25 & 40 & 350 & 12,00 \\
\hline & 6 & 4 & 12 & 40 & 60 & 25 & 40 & 390 & 12,50 \\
\hline & 6 & 4 & 12 & 40 & 60 & 25 & 40 & 400 & 12,50 \\
\hline \multirow{5}{*}{33} & 6 & 5 & 12 & 30 & 60 & 25 & 50 & 240 & 12,00 \\
\hline & 6 & 5 & 12 & 30 & 60 & 25 & 50 & 320 & 13,00 \\
\hline & 6 & 5 & 12 & 30 & 60 & 25 & 50 & 350 & 13,00 \\
\hline & 6 & 5 & 12 & 30 & 60 & 25 & 50 & 390 & 13,50 \\
\hline & 6 & 5 & 12 & 30 & 60 & 25 & 50 & 400 & 13,50 \\
\hline \multirow{5}{*}{34} & 6 & 5 & 12 & 30 & 60 & 30 & 50 & 240 & 12,00 \\
\hline & 6 & 5 & 12 & 30 & 60 & 30 & 50 & 320 & 12,50 \\
\hline & 6 & 5 & 12 & 30 & 60 & 30 & 50 & 350 & 13,00 \\
\hline & 6 & 5 & 12 & 30 & 60 & 30 & 50 & 390 & 13,50 \\
\hline & 6 & 5 & 12 & 30 & 60 & 30 & 50 & 400 & 13,50 \\
\hline \multirow{5}{*}{35} & 6 & 5 & 12 & 40 & 60 & 25 & 50 & 240 & 12,00 \\
\hline & 6 & 5 & 12 & 40 & 60 & 25 & 50 & 320 & 13,00 \\
\hline & 6 & 5 & 12 & 40 & 60 & 25 & 50 & 350 & 13,50 \\
\hline & 6 & 5 & 12 & 40 & 60 & 25 & 50 & 390 & 13,50 \\
\hline & 6 & 5 & 12 & 40 & 60 & 25 & 50 & 400 & 13,50 \\
\hline \multirow{5}{*}{36} & 6 & 5 & 12 & 40 & 60 & 30 & 50 & 240 & 12,00 \\
\hline & 6 & 5 & 12 & 40 & 60 & 30 & 50 & 320 & 12,50 \\
\hline & 6 & 5 & 12 & 40 & 60 & 30 & 50 & 350 & 13,00 \\
\hline & 6 & 5 & 12 & 40 & 60 & 30 & 50 & 390 & 13,50 \\
\hline & 6 & 5 & 12 & 40 & 60 & 30 & 50 & 400 & 13,50 \\
\hline \multirow{5}{*}{37} & 6 & 6 & 12 & 30 & 60 & 30 & 60 & 240 & 12,50 \\
\hline & 6 & 6 & 12 & 30 & 60 & 30 & 60 & 320 & 13,50 \\
\hline & 6 & 6 & 12 & 30 & 60 & 30 & 60 & 350 & 13,50 \\
\hline & 6 & 6 & 12 & 30 & 60 & 30 & 60 & 390 & 14,00 \\
\hline & 6 & 6 & 12 & 30 & 60 & 30 & 60 & 400 & 14,00 \\
\hline \multirow{6}{*}{38} & 6 & 6 & 12 & 40 & 60 & 40 & 60 & 240 & 12,50 \\
\hline & 6 & 6 & 12 & 40 & 60 & 40 & 60 & 320 & 13,00 \\
\hline & 6 & 6 & 12 & 40 & 60 & 40 & 60 & 350 & 13,50 \\
\hline & 6 & 6 & 12 & 40 & 60 & 40 & 60 & 390 & 13,50 \\
\hline & 6 & 6 & 12 & 40 & 60 & 40 & 60 & 400 & 14,00 \\
\hline & 7 & 6 & 20 & 40 & 60 & 40 & 60 & 400 & 15,50 \\
\hline
\end{tabular}

\subsection{Pembahasan Spesifik Atas Variasi Perlakuan Model}

\subsubsection{Variasi Dimensi Balok Tumpuan Sisi Pelat}

Dimensi balok yang diestimasi dengan batasan-batasan lebar balok (bw) diestimasi $1 / 2$ sampai $2 / 3$ dari tinggi penampang balok $(1 / 2 . h t-2 / 3$.ht $)$ dan tinggi penampang balok (ht) diestimasi sebesar 1/12 sampai 1/10 kali panjang bentang balok (1/12.L - 1/10.L) 
memberikan nilai $\alpha_{m}$ selalu lebih besar dari $2\left(\alpha_{m}>2\right)$, sehingga tebal pelat yang ditentukan tidak boleh kurang dari nilai hasil perhitungan dengan formula : $h=\frac{L_{n}\left(0,8+\frac{f y}{1400}\right)}{36+9 \beta}$ dan tidak boleh kurang dari $90 \mathrm{~mm}$. Dengan demikian dari formula itu dapat dilihat bahwa variasi dimensi balok tidak memberikan pengaruh yang signifikan dalam menentukan tebal pelat.

\subsubsection{Variasi Mutu Baja Tulangan}

Hasil perhitungan ketebalan pelat akibat variasi mutu baja tulangan sampai dimensi panel pelat $4 \times 4 \mathrm{~m}^{2}$ dengan formula $h=\frac{L_{n}\left(0,8+\frac{f y}{1400}\right)}{36+9 \beta}$ mendapatkan hasil perhitungan tidak lebih besar dari $90 \mathrm{~mm}$, sehingga ketebalan pelat ditetapkan sebesar 90 $\mathrm{mm}$. Perbedaan setiap variasi mutu baja tulangan baru tampak mulai dari dimensi panel pelat $4 \times 4 \mathrm{~m}^{2}$. Untuk aplikasi secara praktis dan dengan pertimbangan alasan keamanan ketebalan pelat hasil perhitungan diambil dengan nilai terbesar.

\subsubsection{Variasi Kondisi Sisi Pelat}

Variasi kondisi pelat yang dimaksud adalah sisi pelat menerus atau tidak menerus, hal ini membawa konsekwensi saat peninjauan balok dimensi efektif balok akan ditinjau sebagai balok penampang " $T$ " untuk pelat yang sisinya menerus dan akan ditinjau sebagai balok penampang " $\Gamma$ " untuk sisi pelat yang tidak menerus. Hasil perhitungan tidak menunjukkan adanya perbedaan yang signifikan atas perlakukan yang berbeda dari kondisi sisi pelat, dengan demikian posisi panel pelat tidak menentukan dalam menghitung tebal pelat.

\subsubsection{Variasi dimensi panel pelat}

Variasi dimensi panel pelat (Ly $\mathrm{x}$ Lx) menghasilkan nilai tebal pelat dengan perbedaan yang signifikan. Hal ini cukup beralasan karena dalam formula $h=\frac{L_{n}\left(0,8+\frac{f y}{1400}\right)}{36+9 \beta}$, ketebalan pelat merupakan fungsi dari $L_{\mathrm{n}}$ (dimensi bersih panel pelat dalam arah panjang) dan merupakan fungsi dari $\beta$ yang merupakan rasio dari sisi panjang dengan sisi pendek panel pelat lantai. Ketebalan pelat mulai melampaui nilai 
tebal minimum $90 \mathrm{~mm}$ pada dimensi panel $4 \times 4 \mathrm{~m}^{2}$. Untuk aplikasi secara praktis dan dengan pertimbangan alasan keamanan ketebalan pelat hasil perhitungan diambil dengan nilai terbesar

Keseluruhan pembahasan di atas jika diakumulasikan maka ketebalan pelat lantai untuk masing-masing dimensi panel pelat dapat dilihat pada Tabel 4. Pada Tabel ini tampak bahwa informasi yang disajikan masih bersifat khusus, agar bisa diaplikasikan secara umum, maka dasar utama dalam menentukan dimensi tebal pelat adalah dimensi sisi panjang panel pelat. Dimensi panel pelat di antara dua dimensi panel pelat yang berurutan, tebal pelat diambil pada nomor urut yang lebih besar. Sebagai contoh panel pelat dengan dimensi $5,0 \times 3,5 \mathrm{~m}^{2}$, maka jika melihat urutan dimensinya panel pelat ini berada di antara urutan nomor 3 dan nomor 4 . Tebal pelat ditentukan sesuai dengan tebal pelat pada panel pelat pada urutan nomor 4, sehingga tebal pelatnya adalah $11,00 \mathrm{~cm}$.

Tabel 2. Tebal pelat menurut dimensi panel pelat.

\begin{tabular}{|c|c|c|}
\hline No. & $\begin{array}{c}\text { Dimensi Panel Pelat } \\
{\left[\mathrm{M}^{2}\right]}\end{array}$ & $\begin{array}{c}\text { Tebal Pelat Lantai } \\
{[\mathrm{CM}]}\end{array}$ \\
\hline 1 & $3 \times 3$ & 9,00 \\
\hline 2 & $4 \times 3$ & 9,00 \\
\hline 3 & $4 \times 4$ & 9,50 \\
\hline 4 & $5 \times 3$ & 10,50 \\
\hline 5 & $5 \times 4$ & 11,00 \\
\hline 6 & $5 \times 5$ & 11,50 \\
\hline 7 & $6 \times 3$ & 11,50 \\
\hline 8 & $6 \times 4$ & 12,50 \\
\hline 9 & $6 \times 5$ & 13,50 \\
\hline 10 & $6 \times 6$ & 14,00 \\
\hline 11 & $7 \times 6$ & 15,50 \\
\hline
\end{tabular}

Sumber : Hasil analisis

\section{PENUTUP}

\subsection{Simpulan}

Hasil analisa berbagai kasus dimensi panel pelat secara menyimpulkam ketebalan pelat lantai gedung yang ditumpu pada keempat sisinya sebagai berikut : panel pelat $3 \times 3 \mathrm{~m}^{2}$ tebal pelat $=90 \mathrm{~mm}$, panel pelat $4 \times 3 \mathrm{~m}^{2}$ tebal pelat $=90 \mathrm{~mm}$, panel pelat $4 \times 4 \mathrm{~m}^{2}$ tebal pelat $=95 \mathrm{~mm}$, panel pelat $5 \times 3 \mathrm{~m}^{2}$ tebal pelat $=105 \mathrm{~mm}$, panel pelat $5 \times 4 \mathrm{~m}^{2}$ tebal pelat $=110 \mathrm{~mm}$, panel pelat $5 \times 5 \mathrm{~m}^{2}$ tebal pelat $=115 \mathrm{~mm}$, panel pelat $6 \times 3 \mathrm{~m}^{2}$ tebal pelat $=115 \mathrm{~mm}$, panel pelat $6 \times 4 \mathrm{~m}^{2}$ tebal pelat $=$ 
$125 \mathrm{~mm}$ panel pelat $6 \times 5 \mathrm{~m}^{2}$ tebal pelat $=135 \mathrm{~mm}$, panel pelat $6 \times 6 \mathrm{~m}^{2}$ tebal pelat $=140 \mathrm{~mm}$ dan panel pelat $7 \times 6 \mathrm{~m}^{2}$ tebal pelat $=155 \mathrm{~mm}$.

\subsection{Saran}

Ketebalan pelat pada simpulan adalah hasil analisis adalah untuk sistem pelat dua arah (Two way Slab) dengan mengambil dimensi balok pada sisi pelat sebagai tumpuan pelat dengan batasan-batasan sebagai berikut : Dimensi tinggi balok diambil sebesar 1/12$1 / 10$ kali panjang bentang yang bersesuaian $(1 / 12 \mathrm{~L}-1 / 10 \mathrm{~L})$ dan dimensi lebar balok diambil sebesar $1 / 2-2 / 3$ kali dimensi tinggi balok $(1 / 2 \mathrm{~h}-2 / 3 \mathrm{~h})$, oleh karena itu untuk mengurangi hasil perhitungan yang bias, saat perencanaan balok dimensi balok disarankan untuk mengikuti batasan-batasan tersebut diatas.

Untuk meyakinkan keamanan hasil perhitungan, bahwa ketebalan pelat yang diambil cukup aman dan ekonomis, sebaiknya dilakukan penelitian lanjutan untuk menentukan besar lendutan yang terjadi sehingga ketebalan pelat yang diambil saat dibebani menunjukkan prilaku pelat yang betul-betul aman terhadap kemungkinan adanya kegagalan konstruksi.

\section{DAFTAR PUSTAKA}

1. Anonimous, 2013, Standar Nasional Indonesia (SNI), Persyaratan Beton Struktural untuk Bangunan Gedung (SNI-2847:2013), Badan Standarisasi Nasional, Jakarta

2. Departemen Pekerjaan Umum, 1971, Peraturan Beton Indonesia (NI-2), Yayasan LPMB, Bandung

3. Nawy, E. G. 1990, Beton Bertulang Suatu Pendekatan Dasar, PT Eresco, Bandung

4. Setiawan, A. 2016, Perancangan Struktur Beton Bertulang Penerbit Erlangga, Jakarta

5. Wang, C. K. Salmon, C. G. S, Hariandja, B. 1987, Disain Beton Bertulang Jilid 2. Penerbit Erlangga, Jakarta 